\section{Tackling Cost: A Prescription for Spending Wisely}

W e all know cancer drugs cost too much. Every new drug is priced according to the competitive market, not based on what it cost to develop or even on its value. Even generic drugs have escalated in price as the competitive market for these agents has narrowed the field. We all complain about it, but what are we really doing about it?

By the way, this isn't just an oncology problem. The cost of life-saving drugs like insulin and epinephrine has skyrocketed, forcing many people with marginal insurance or a high deductible to make tough choices about managing their health or paying their rent. It isn't right.

Ironically, of course, drugs are much cheaper in many other countries. Most notably, our neighbors to the north in Canada pay a fraction of what we do in the United States. With national health insurance for all, each province can bid competitively for what they need. They can also choose which drugs, with the highest value for the cost, they want to have on the formulary. You would think CMS could have that option here, but legally, they are prohibited from negotiating on price.

Nor is this the FDA's problem. That agency has plenty to do reviewing and approving drugs and ensuring their safety. We can't put more on their shoulders.

Insurance providers are another stakeholder, but they basically must cover what the FDA approves. So if the cost rises, so do premiums. It's a vicious circle.

Coupled with cost is the problem of look-alike drugs. How many antiangiogenesis inhibitors or checkpoint inhibitors do we really need? But these are very useful drugs across many disease indications, so a company with a new PD-1 or PD-L1 inhibitor can usually find some gap to fill, show efficacy, and get FDA approval.

This, I think, is where we come in. I see several possibilities. We have the opportunity to partner with CMS and other entities on research to establish value. Companies have no incentive to do this for us, but CMS could. The FDA has set a precedent to perform small trials to establish efficacy for biosimilars. Why couldn't the same be done with drugs in a similar class? Why wouldn't CMS or even large HMOs like Kaiser Permanente want to fund these studies? This could allow us to substitute freely while considering cost.

Another possibility would be to escalate a program NCCN has already started. Several years ago, NCCN started creating evidence blocks in the NCCN Clinical Practice Guidelines in Oncology (NCCN Guidelines) which included cost. These have mostly been informational and probably haven't yet had the impact NCCN hoped for. How about taking this one step further and moving cost directly into the algorithm? In fact, in the 2017 update of the NCCN Guidelines for Non-Small Cell Lung Cancer, the panel took cost-effectiveness as an argument to remove a drug regimen from the algorithm when studies suggested that the limited improvement in efficacy was not worth the additional cost and toxicity. (More information is provided in The Last Word, page 760.) Now that ought to be a wake-up call for the industry!

Judging from the climate in Washington these days, I don't think the government is going to fix the cost of care. But we can, and should, do our part. People are suffering in many ways from the cost of drugs. It's our job to help. JNCCN@nccn.org or log into www.editorialmanager.com/JNCCN.

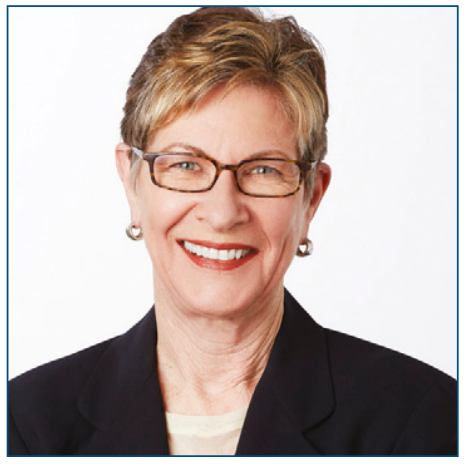

MARGARET TEMPERO, MD

Margaret Tempero, MD, is a Professor of Medicine and Director of the UCSF Pancreas Center and editor-in-chief of JNCCN. Her research career has focused on pancreatic ductal adenocarcinoma, especially in the area of investigational therapeutics. Dr. Tempero has served on the ASCO Board of Directors and as ASCO President. She currently serves on the ASCO Conquer Cancer Foundation Board. She codirected the AACR/ASCO Methods in Clinical Cancer Research and taught this course and similar courses in Europe and Australia. She was founding Chair of the $\mathrm{NCl}$ Clinical Oncology Study Section and served as a member and Chair of the $\mathrm{NCl}$ Board of Scientific Counselors Subcommittee A. She is a member of the Scientific Steering Committee and Chair of the Clinical and Translational Study Section for the Cancer Prevention \& Research Institute of Texas. She is or has been on the Scientific Advisory Boards of the Lustgarten Foundation, the Pancreatic Cancer Action Network, the V Foundation, The Alberta Canada Cancer Board, and the EORTC. She served as a member of the Oncology Drug Advisory Committee for the FDA. She has served as Deputy Director and Interim Director for the UNMC Eppley Cancer Center. She is Chief Emeritus of the Division of Medical Oncology at UCSF. She served as the founding Deputy Director and was later Director of Research Programs at the UCSF Helen Diller Family Comprehensive Cancer Center.

doi: $10.6004 /$ jnccn.2019.0030

The ideas and viewpoints expressed in this editorial are those of the author and do not necessarily represent any policy, position, or program of NCCN. 